\title{
PENGARUH PEMBERIAN EKSTRAK Sargassum sp. DENGAN PELARUT METANOL PADA PAKAN TERHADAP JUMLAH ERITROSIT DAN DIFFERENSIAL LEUKOSIT IKAN LELE DUMBO (Clarias gariepinus)
}

\author{
EFFECT OF EXTRACT Sargassum sp. WITH METHANOL SOLVENT IN FEED ON \\ ERYTHROCYTHES AND DIFFERENTIAL LEUCOCYTHES OF AFRICAN CATFISH (Clarias \\ gariepinus)
}

\author{
Firly Waliani Rahma, Gunanti Mahasri dan Laksmi Surmartiwi \\ Fakultas Perikanan dan Kelautan Universitas Airlangga \\ Kampus C Mulyorejo - Surabaya, 60115 Telp. 031-5911451
}

\begin{abstract}
The main obstacles in successful production is the attack of a disease. Preventive measures in reducing disease one of them is by means an increase in immunity the body of fish use natural compound (Parelberg et al., 2005). One of the natural compound that can be used as obtaining the immune system fish are the vitamin C, iodine, tannin (Bachtiar, dkk., 2012) and polysaccharides and derivatives as fucoidan. (Castro et. al., 2006) which is in Sargassum sp. With the provision of extract Sargassum sp. in feed is expected to optimize the number of erythrocytes and differensial leukocytes (number of neutrophils, monocytes and lymphocytes) at african catfish (Clarias gariepinus) so that it may optimize immunity the body of fish (Brown, 2000). The result of the observation of the blood of fish test is the use of extract Sargassum sp. wich get mixed in feed with doses 5, 10 and $15 \mathrm{~g} /$ kilogram feed during 21 days impact on the number of erythrocytes and prosentase lymphocytes blood catfishes. In doses $\mathrm{C}(15 \mathrm{~g}$ extract/ kilogram feed) put a value erythrocytes highest in day 21 namely $16.84 \pm 1.56 \times 105$ cells $/ \mathrm{mm}^{3}$, and give prosentase lymphocytes highest in day 21 than those wich others are $86.00 \pm 3.81 \%$. But in a post test, $\mathrm{B}$ and $\mathrm{C}$ not seen the real difference between treatment. While for statistics the addition of extract not indicates the influence of real to the percentage neutrophils and monocytes of the blood fish. So that it can be said that addition extract Sargassum sp. with doses $15 \mathrm{~g}$ extract/kilogram feed give the effectiveness of the optimal response immune system than second doses other.
\end{abstract}

Keywords : Feed, ekstract Sargassum sp., the number of erythrocytes, and differential leukocytes

\section{Pendahuluan}

Ikan lele merupakan salah satu komoditas unggulan air tawar yang penting dalam rangka pemenuhan gizi masyarakat. Selain karena rasanya yang enak dan harga dari ikan ini dapat terjangkau oleh seluruh lapisan masyarakat kandungan protein dari ikan lele sebesar 15,74 \% (Ubadillah dan Hersoelistyorini, 2010). Produksi ikan lele pada tahun 2010 sebesar 242.811 ton dan pada tahun 2013 meningkat menjadi 758.455 ton. Kenaikan rata-rata produksi ikan lele selama tahun 20102013 sebesar 47,21\%. Target produksi ikan lele pada tahun 2014 ditingkatkan menjadi 840.000 ton. (KKP, 2013). Namun, salah satu yang menjadi kendala dalam budidaya ikan lele adalah rentan terhadap kondisi lingkungan yang buruk sehingga mudah terinfeksi bakteri (Murhananto, 2002).

Upaya pencegahan yang paling efektif dilakukan dengan meningkatkan kekebalan tubuh ikan baik kekebalan tubuh spesifik dengan menggunakan vaksinasi maupun kekebalan tubuh non spesifik dengan pemberian imunostimulan (Parelberg et al., 2005).

Salah satu bahan alami yang mampu meningkatkan sistem kekebalan tubuh ikan yakni Sargassum sp. menurut Castro et. al. (2006) mengandung senyawa fucoidan yang merupakan polisakarida kompleks pada dinding sel alga coklat dan merupakan komponen terbesar yang mampu meningkatkan imunitas dengan merangsang produksi sel-sel imun, sehingga membantu dalam melawan bakteri patogen. Selain itu Sargasum sp. mengandung iodin, tannin dan fenol yang berfungsi untuk menghambat pertumbuhan bakteri (Bachtiar, dkk., 2012)

Darah menjadi salah satu cara dalam mendiagnostik status kesehatan dari ikan. Darah mengalami perubahan yang serius khususnya apabila terkena penyakit infeksi (Amlacher 1970). Parameter darah yang dapat memperlihatkan adanya gangguan adalah nilai hematokrit, konsentrasi hemoglobin, jumlah eritrosit (sel darah merah) dan serta perubahan 
terhadap jumlah differensial leukosit (neutrofil, monosit dan limfosit) (Lagler et al., 1977).

\section{Materi dan Metode}

Penelitian ini dilaksanakan di

Laboratorium Pendidikan Fakultas Perikanan dan Kelautan Universitas Airlangga selama 21 hari dimulai pada bulan Agustus sampai dengan bulan September 2015. Metode yang digunakan dalam penelitian ini adalah eksperimental dengan Rancangan Acak Lengkap (RAL). Perlakuan yang digunakan sebanyak 4 perlakuan dan 5 ulangan. Pemberian pakan dengan perlakuan diberikan selama 21 hari dan pada hari ke $0,7,14$ dan 21 dilakukan pengitungan jumlah eritrosit dan differensial leukosit (neutrofil, limfosit dan monosit). Perlakuan yang diberikan yakni perbedaan dosis ekstrak Sargassum sp. yakni K (Kontrol), A (5 gr ekstrak/kg pakan), B (10 gr ekstrak/kg pakan) dan C (15 gr ekstrak/kg pakan). Jumlah pakan yang diberikan sebanyak 5\% dari biomassa.

Bahan Penelitian

Bahan yang digunakan dalam penelitian ini antar lain adalah ikan lele dumbo (Clarias gariepinus) ukuran 10-12 cm, sebanyak 200 ekor. Sargassum sp., Aquades, pakan ikan komersial Comfeed 781-2 dengan kandungan protein $30-32 \%$, formalin, kapas, tisu, EDTA, Giemsa 10\%, metil alcohol

Penghitungan Jumlah Eritrosit (Svobodova \& Vyukusova 1991)

Jumlah eritrosit dihitung dalam volume tertentu dengan menggunakan faktor konversi. Penghitungan dimulai dengan mengisi pipet eritrosit yakni darah dihisap sampai garis tanda 0,5 dan larutan pengencer (larutan hayem) sampai garis 101. Melepaskan tabung aspirator kemudian dihomogenkan 5-10 menit untuk memastikan pencampuran dengan baik. Membuang 3-4 tetes pertama, berikutnya meletakkan pada bilik hitung. Bilik hitung yang telah terisi diletakkan pada mikroskop dan lakukan pembacaan dalam pembesaran (40x).

$$
\text { Eritrosit }=(\mathrm{A} / \mathrm{N}) \times(1 / \mathrm{V}) \times \mathrm{Fp}
$$

$\mathrm{A}=\Sigma$ sel terhitung

$\mathrm{V}=$ volume kotak haemacytometer

$\mathrm{N}=\Sigma$ kotak haemacytometer yang diamati

$\mathrm{Fp}=$ Faktor pengenceran

Penghitungan Prosentase Differensial Leukosit (Svobodova \& Vyukusova 1991)

Pemeriksaan dilakukan dengan membuat preparat ulas darah dan diwarnai dengan pewarnaan Giemsa 10\% selama 10-15 menit. Sampel darah di campur homogen sebelum diambil dengan pipet kapiler, kemudian satu tetes kecil darah diletakkan dekat ujung gelas obyek posisi permukaan datar. Gelas obyek yang kedua ditempatkan dengan ujung menyentuh permukaan gelas obyek pertama sehingga membentuk sudut $30-45^{\circ}$. Gelas obyek kedua ditarik ke samping dan dibiarkan darah mengalir dengan daya kapiler sehingga mencapai luasan $2 / 3$ gelas obyek pertama. Gelas obyek kedua didorong dengan sudut yang sama sehingga membentuk lapisan tipis. Preparat apus dibiarkan mengering di udara terbuka.

Preparat apus darah difiksasi dengan metil alkohol selama 3-5 menit, preparat diambil dan dibiarkan kering di udara. Setelah kering preparat direndam dengan pewarna Giemsa yang baru selama 10-15 menit. Preparat dicuci dengan air berkali-kali dan dibiarkan mengering di rak. Penghitungan persentase limfosit dilakukan perbesaran obyektif 40x, klasifikasi leukosit pada beberapa lapang pandang dan dihitung per 100 leukosit.

$$
\begin{aligned}
& \text { Presentase Limfosit }=\frac{\frac{L}{100} \times 100 \%}{\frac{M}{100} \times 100 \%} \\
& \text { Presentase Monosit }=\frac{N}{100} \times 100 \% \\
& \text { Presentase Neutrofil }=
\end{aligned}
$$

\section{Hasil dan Pembahasan}

Jumlah Eritrosit

Pengamatan terhadap jumlah total eritrosit dalam darah ikan lele dumbo pada perlakuan yang berbeda, menunjukkan bahwa nilai tertinggi terdapat pada perlakuan $\mathrm{C}$ pada hari ke-21 yakni $16.84 \pm 1.56 \times 10^{5} \mathrm{sel} / \mathrm{mm}^{3}$. Nilai terendah terdapat pada kontrol yaitu 11.6 $\pm 5.80 \times 10^{5} \mathrm{sel} / \mathrm{mm}^{3}$ yakni pada hari ke-14. Dari analisa statistic ragam (ANOVA) dan uji lanjutan Duncan pada selang kepercayaan 95\% $(\mathrm{p}<0.05)$ diperoleh hasil pada hari ke-21 kontrol berbeda nyata $(\mathrm{p}<0.05)$ dengan perlakuan A, B dan $\mathrm{C}$ yakni jumlah eritrosit lebih rendah dari ketiga perlakuan. Kisaran jumlah eritrosit ini masih berada dalam kisaran normal artinya ikan berada dalam kondisi sehat. Hal ini sesuai dengan pernyataan Robert (1978) dalam Mulyani (2006) yang menyatakan bahwa pada ikan teleostei, jumlah normal eritrosit sebesar $1,05-3,00 \times 10^{6} \mathrm{sel} / \mathrm{mm}^{3}$. 
Tabel 1. Jumlah Rataan Eritrosit Pada Setiap Perlakuan (x $10^{5} \mathrm{sel} / \mathrm{mm}^{3}$ ) Selama Pemberian Ekstrak Sargassum sp.

\begin{tabular}{cccccc}
\hline Perlakuan & Hari ke-0 & Hari ke-7 & Hari ke-14 & Hari ke-21 & Normal \\
\hline K & $14.24 \pm 2.36$ & $13.6 \pm 5.80$ & $15.18 \pm 2.82$ & $13.08 \pm 0.82^{\mathrm{a}}$ & $1,05-3,0$ \\
A & $13.38 \pm 4.92$ & $13.74 \pm 1.86$ & $15.10 \pm 2.50$ & $16.10 \pm 1.60^{\mathrm{b}}$ & $\times 10^{6}$ \\
B & $12.78 \pm 1.42$ & $13.28 \pm 4.52$ & $15.50 \pm 1.80$ & $16.06 \pm 1.34^{\mathrm{b}}$ & $\begin{array}{c}\text { Robert, } 1978 \\
\text { dalam }\end{array}$ \\
C & $13.58 \pm 2.72$ & $13.98 \pm 1.52$ & $15.34 \pm 2.36$ & $16.84 \pm 1.56^{\mathrm{b}}$ & $\begin{array}{c}\text { Mulyani, } \\
2006\end{array}$ \\
\hline
\end{tabular}

Keterangan : Huruf superscrift yang berbeda pada kolom yang sama menunjukkan pengaruh berbeda nyata $(\mathrm{p}<0.05)$

Tabel 2. Persentase Rataan Limfosit Setiap Perlakuan (\%) Selama Pemberian Ekstrak Sargassum sp.

\begin{tabular}{cccccc}
\hline Perlakuan & Hari ke- 0 & Hari ke-7 & Hari ke-14 & Hari ke-21 & Normal \\
\hline K & $78.80 \pm 4.32$ & $81.60 \pm 2.41$ & $81.40 \pm 1.67$ & $80.80 \pm 1.92^{\mathrm{a}}$ & \\
A & $80.40 \pm 1.14$ & $83.00 \pm 3.39$ & $82.80 \pm 3.56$ & $85.80 \pm 3.11^{\mathrm{b}}$ & $65,20-86,00$ \\
B & $77.60 \pm 4.93$ & $81.60 \pm 2.19$ & $84.00 \pm 3.54$ & $85.20 \pm 3.11^{\mathrm{b}}$ & Salasia dkk., \\
C & $80.20 \pm 2.86$ & $81.00 \pm 2.92$ & $85.40 \pm 4.04$ & $86.00 \pm 3.81^{\mathrm{b}}$ & $(2001)$ \\
\hline
\end{tabular}

Tabel 3. Jumlah Rataan Persentase Jumlah Neutrofil Pada Setiap Perlakuan (\%) Selama Pemberian Ekstrak Sargassum sp.

\begin{tabular}{cccccc}
\hline Perlakuan & Hari ke-0 & Hari ke-7 & Hari ke-14 & Hari ke-21 & Normal \\
\hline K & $13.00 \pm 4.95$ & $10.60 \pm 2.07$ & $10.60 \pm 1.82$ & $11.20 \pm 1.58$ & \\
A & $11.40 \pm 1.82$ & $9.00 \pm 2.83$ & $8.20 \pm 3.96$ & $7.80 \pm 1.10$ & $7,75-14,94$ \\
B & $13.40 \pm 4.51$ & $10.40 \pm 3.05$ & $7.20 \pm 1.44$ & $8.40 \pm 1.67$ & Salasia dkk., \\
C & $11.40 \pm 2.82$ & $11.00 \pm 3.32$ & $8.20 \pm 2.28$ & $8.20 \pm 1.92$ & $(2001)$ \\
\hline
\end{tabular}

Tabel 4. Jumlah Rataan Persentase Jumlah Monosit Pada Setiap Perlakuan (\%) Selama Pemberian Ekstrak Sargassum sp.

\begin{tabular}{cccccc}
\hline Perlakuan & Hari ke-0 & Hari ke-7 & Hari ke-14 & Hari ke-21 & Normal \\
\hline K & $8.20 \pm 0.84$ & $7.80 \pm 0.45$ & $8.00 \pm 0.71$ & $8.60 \pm 1.52$ & \\
A & $8.20 \pm 0.84$ & $8.00 \pm 1.00$ & $7.70 \pm 0.71$ & $7.40 \pm 1.95$ & $3,12-8,82$ \\
B & $9.00 \pm 0.71$ & $7.00 \pm 1.00$ & $8.80 \pm 0.45$ & $8.20 \pm 0.84$ & $\begin{array}{c}\text { Andani dkk. } \\
\text { C }\end{array}$ \\
\hline
\end{tabular}

Sel darah merah mengandung hemoglobin yang memungkinkan sel darah merah membawa oksigen ke seluruh jaringan tubuh. Rendahnya eritrosit akan menyebabkan ikan tidak mampu mengambil oksigen dalam jumlah banyak walaupun ketersediaan oksigen di perairan mencukupi. Akibatnya ikan akan mengalami anoxia (kekurangan oksigen) (Fujaya, 2002). Seperti halnya pada hematokrit, kadar eritrosit yang rendah menunjukkan terjadinya anemia sedangkan kadar yang tinggi menunjukkan bahwa ikan dalam keadaan stress (Wedemeyer dan Yatsuke, 1977 dalam Purwanto, 2006).

Differential Leukosit
Bila dilihat pada Tabel 2. jumlah prosentase limfosit di semua perlakuan dari hari ke-0 sampai hari ke-21 cenderung meningkat. Peningkatan prosentase limfosit di hari ke-21 pada perlakuan 5, 10 dan $15 \mathrm{~g}$ ekstrak / $\mathrm{kg}$ pakan menunjukkan pemberian ekstrak Sargassum sp. memberikan pengaruh terhadap prosentase limfosit dalam darah ikan lele. Pengaruh ini berupa peningkatan jumlah limfosit. Hal ini dikarenakan kandungan kimia alami dari hasil ekstraksi Sargassum sp. mengandung vitamin $\mathrm{C}$ dimana pemberian vitamin $\mathrm{C}$ dalam dosis tinggi mampu meningkatkan ketahanan tubuh (Navarre and Halve, 1989) dan polisakarida yang berfungsi 
sebagai peningkat sistem imun pada ikan dan meningkatkan proteksi terhadap bakteri (Anggadiredja dkk., 2006). Selain itu kandungan lain dalam ekstrak Sargassum sp. seperti senyawa fucoidan juga berfungsi meningkatkan sel imun dengan merangsang produksi sel imun (Castro el al., 2006), yakni menginduksi sel pembentuk leukosit, untuk menghasilkan lebih banyak sel sel yang terdapat dalam leukosit yakni limfosit, monosit dan neutrofil (Radji, 2015). Induksi sel leukosit ini merupakan bentuk respon dari tubuh ikan terhadap adanya benda asing yang masuk se dalam tubuh. Benda asing ini berupa pemberian ekstrak Sargassum sp. yang dicampurkan ke dalam pakan.

Peningkatan prosentase limfosit merupakan refleksi keberhasilan sistem imunitas ikan dalam mengembangkan respon imunitas seluler (non spesifik) sebagai pemicu untuk respon kekebalan. Pada dasarnya sel limfosit terdiri dari dua populasi : sel B dan sel T. Sel B mempunyai kemampuan untuk bertransformasi menjadi sel plasma yaitu sel yang memproduksi antibodi. Sedangkan sel $\mathrm{T}$ sangat berperan dalam kekebalan berperantara sel (sel $\mathrm{T}$ sitotoksik) dan mengontrol respon imun (sel $\mathrm{T}$ supresor). Limfosit yang teraktivasi akan berdiferensiasi dari sel kognitif yang mengenal antigen menjadi sel efektor yang berfungsi menyingkirkan anti gen menjadi sel efektor yang berfungsi menyingkirkan antigen (Kresno, 2001). Setelah terjadi pengikatan antigen dengan reseptor antigen sel limfosit, maka sel limfosit akan membelah dan berdiferensiasi menjadi sel efektor dan sel memori (Tizard 1988). Sel T-sitolitik yang berdifferensiasi mempunyai granula sitoplasmik lebih banyak yang mengandung protein yang berfungsi melisiskan sasaran. Limfosit B berdifferensiasi menjadi sel plasma yang memproduksi antibodi (Kresno, 2001).

Pengamatan terhadap rataan persentase neutrofil dalam darah ikan lele dumbo menunjukkan bahwa jumlah neutrofil cenderung menurun disetiap minggunya. Pada dosis kontrol, 5, 10 dan $15 \mathrm{~g}$ ekstrak/ kg pakan prosentase neutrofil memiliki pola yang sama yakni cenderung menurun. Menurut Tizard (1988), hal ini berkaitan dengan fungsi utama dari neutrofil yaitu penghancuran bahan asing melalui proses fagositosis yaitu kemotaksis dimana sel akan bermigrasi menuju partikel, peletakan partikel pada sel, penelanan partikel oleh sel, dan penghancuran partikel oleh enzim lisosim di dalam fagolisosom. Sehingga tanpa adanya rangsangan dari benda asing baik berupa bakteri, virus, maupun patogen neutrofil tidak akan menunjukkan reaksi peningkatan. Pernyataan ini dikuatkan oleh pendapat Delman and Brown (1989) yang menyatakan bahwa peningkatan jumlah sel neutrofil mengindikasikan adanya peningkatan kegiatan pengumpulan makrofag di tempat terjadinya infeksi, sehingga makrofag akan lebih mudah untuk menghancurkan partikel asing. Namun pasca infeksi jumlah sel neutrofil dapat ditekan, sel-sel mati dan jaringan nekrotik yang salah satunya mengandung neutrofil yang telah mati secara bertahap akan mengalami lisis dalam beberapa hari (Jain, 1993).

Monosit yang cenderung menurun di setiap minggunya berkaitan dengan fungsi monosit yaitu sebagai makrofag, dimana monosit tidak dibutuhkan untuk memfagosit, dikarenakan belum adanya infeksi yang masuk ke dalam tubuh yang merangsang produksi monosit. Gambar 9 dapat dilihat bahwa persentase monosit di perlakuan 0, 510 dan 15 g ekstrak/ kg pakan memiliki pola yang sama yakni akan mengalami penurunan di hari ke-7 hingga hari ke-21. Erika (2008) yang menyatakan hal yang serupa bahwa jumlah limfosit yang rendah dalam sirkulasi darah akan diimbangi dengan jumlah neutrofil yang tinggi, begitupun sebaliknya.

\section{Kesimpulan}

Kesimpulan dari penelitian ini adalah Penggunaan ekstrak Sargassum sp. dengan pelarut metanol yang dicampurkan pada pakan berpengaruh terhadap peningkatan jumlah eritrosit dan prosentase limfosit darah ikan lele dumbo namun tidak berpengaruh pada ikan prosentase monosit dan neutrofil. Dosis pemberian ekstrak sebanyak $15 \mathrm{~g}$ ekstrak $/ \mathrm{kg}$ pakan mampu memberikan peningkatan jumlah eritrosit dan limfosit paling optimal dibandingkan dosis 5 dan $10 \mathrm{~g}$ ekstrak / kg pakan. Perlu dilakukan penelitian lebihlanjut pula mengenai waktu optimum pemberian ekstrak agar penggunaannya tepat guna dan dapat memberikan respon yang optimum terhadap sistem pertahanan nonspesifik ikan. Selain itu, perlu dilakukan penelitian mengenai kemungkinan efek samping dari pemberian ekstrak yang dicampurkan dalam pakan pada ikan.

\section{Daftar Pustaka}

Amlacher, E. 1970. Textbook of fish disease. Publication Nepture City . New Jersey. USA

Anggadiredja, J. T., Ahmad Z, Heri P dan Sri I 2006. Rumput Laut. Penerbit Swadaya. Jakarta. 
Bachtiar, S.Y., W. Tjahjaningsih dan N. Sianita. 2012. Pengaruh Ekstrak Alga Coklat (Sargassum sp.) Terhadap Pertumbuhan Bakteri Escherichia coli. Journal of Marine and Coastal Science 1(1) : 53-60.

Brown, B.A. 1980. Hematology Principles and Procedores. Third Edition. Lea and Febiger. Philadelphia.

Castro, R. I. Zarrab, \& J. Lamas. 2004. Watersoluble Seaweed Extracts Modulate the Pantoea agglomerans lippolysaccharide (LPS). Fish Shellfish Immunol (10) : 555-558

Dellman H.D. dan Brown E.M. 1992. Buku Teks Histologi Veteriner. Edisi 3. Hartono (Penerjemah). UI Press, Jakarta

Erika, Y. 2008. Gambaran Diferensiasi Leukosit pada Ikan Mujair (Oreochromis mossambica) di Daerah Ciampea Bogor. (Skripsi). Institut Pertanian Bogor.

Fujaya, Y. 2002. Fisiologi Ikan. Proyek Peningkatan Penelitian Pendidikan Tinggi Direktorat Jendral Pendidikan Tinggi Departemen Pendidikan Nasional.

Houghton P.J and Raman. 1998. Laboratory Handbook for The Fractination of Natural Etract. Chapman and Hall. London. UK. 199 pp.

Jain, N.C. 1993. Essentials of Veterinary Hematology. Lea and Febiger Publishing. Philadelphia. 417p.

Kementrian Kelautan dan Perikanan. 2013. Laporan Tahunan Direktorat Produksi Tahun 2013. Direktorat Jendral Perikanan Budidaya Jakarta. Diakses dari www.djpb.kkp.go.id (10 Juni 2015).

Kresno, S.B. 2001. Imunologi : Diagnosis dan Prosedur Laboratorium. Edisi Ketiga. Fakultas Kedokteran. Universitas Indonesia. Jakarta. 437 hlm.
Lagler KF, Bardach JE, RR Miller, Passino DRM. 1977. Ichthyology. John Willey and Sons. Inc. new York-London. 506 hal.

Mulyani, S. 2006. Gambaran Darah Ikan Gurame Osphronemus gouramy Yang Terinfeksi Cendawan Achlya sp. pada Kepadatan 320 dan 720 Sppora per mL. Skripsi. Program Studi Budidaya Perairan, Fakultas Perikanan dan Ilmu Kelautan, Institut Pertanian Bogor.

Navarre, O. and J. E. Halver. 1989. Disease Resistence and Humoral Antibody Production in Rainbow Trout Fed High Levels of Vitamin C. 79 : 207-221

Parelberg, A., A. Ronen., M. Hutoran., Y. Smith and M. Kotler. 2005. Protection of cultured Cyprinus carpio disease by an attenuated virus vaccine. J. Vaccine 23: 3396-3403.

Purwanto, A. 2006. Gambaran Darah Ikan Mas Cyprinus carpio Yang Terinfeksi Koi Herpes Virus. Skripsi. Program Studi Budidaya Perairan, Fakultas Perikanan dan Ilmu Kelautan, Institut Pertanian Bogor.

Radji, M. 2015. Imunologi dan Virologi : Edisi Revisi. Isfi Penerbitan. Jakarta. 354 hal.

Svobodova Z, Vyukusova B. 1991. Diagnostik, Prevention and Therapy of Fish Disease and Intoxication. Research Institute of fish Culture and Hydrobiology Vodnany Czechoslovakia. http//www.fao.org/fi/website/ firetriveaction.do?dom=topic $\&$ fid $=160$ 64\&lang=en diakses : 21 September 2015

Tizard I. 1982. Veterinary Immunology, An Introduction. Ed Ke-3. W,B. Saunders Company, Canada. 
Pengaruh Pemberian Ekstrak...... 